\title{
Addressing the Water-Energy-Food Nexus through Enhanced Green Roof Performance
}

\author{
Jeremy Wright ${ }^{1}\left(\mathbb{D}\right.$, Jeremy Lytle $^{2}$, Devon Santillo ${ }^{3}$, Luzalen Marcos ${ }^{3}$ and Kristiina Valter Mai ${ }^{3, *(D)}$ \\ 1 Environmental Applied Science and Management Program, Ryerson University, 350 Victoria Street, Toronto, \\ ON M5B 2K3, Canada; jeremy.wright@ryerson.ca \\ 2 Building Science Program, Faculty of Engineering and Architectural Science, Ryerson University, \\ 350 Victoria Street, Toronto, ON M5B 2K3, Canada; jeremy.lytle@ryerson.ca \\ 3 Department of Electrical, Computer and Biomedical Engineering, Faculty of Engineering and Architectural \\ Science, Ryerson University, 350 Victoria Street, Toronto, ON M5B 2K3, Canada; dsantillo@ryerson.ca (D.S.); \\ lmarcos@ryerson.ca (L.M.) \\ * Correspondence: kvmai@ryerson.ca
}

Citation: Wright, J.; Lytle, J.; Santillo, D.; Marcos, L.; Mai, K.V. Addressing the Water-Energy-Food Nexus through Enhanced Green Roof Performance. Sustainability 2021, 13, 1972. https://doi.org/10.3390/ su13041972

Academic Editor: Elena Cristina Rada Received: 7 December 2020

Accepted: 8 February 2021

Published: 11 February 2021

Publisher's Note: MDPI stays neutral with regard to jurisdictional claims in published maps and institutional affiliations.

Copyright: (c) 2021 by the authors. Licensee MDPI, Basel, Switzerland. This article is an open access article distributed under the terms and conditions of the Creative Commons Attribution (CC BY) license (https:// creativecommons.org/licenses/by/ $4.0 /)$.

\begin{abstract}
Urban densification and climate change are creating a multitude of issues for cities around the globe. Contributing factors include increased impervious surfaces that result in poor stormwater management, rising urban temperatures, poor air quality, and a lack of available green space. In the context of volatile weather, there are growing concerns regarding the effects of increased intense rainfalls and how they affect highly populated areas. Green roofs are becoming a stormwater management tool, occupying a growing area of urban roof space in many developed cities. In addition to the water-centric approach to the implementation of green roofs, these systems offer a multitude of benefits across the urban water-energy-food nexus. This paper provides insight to green roof systems available that can be utilized as tools to mitigate the effects of climate change in urbanized areas. A new array of green roof testing modules is presented along with research methods employed to address current issues related to food, energy and water performance optimization. Rainwater runoff after three rain events was observed to be reduced commensurate with the presence of a blue roof retention membrane in the testbed, the growing media depth and type, as well as the productive nature of the plants in the testbed. Preliminary observations indicate that more productive green roof systems may have increasingly positive benefits across the water-energy-food nexus in dense urban areas that are vulnerable to climate disruption.
\end{abstract}

Keywords: green roofs; stormwater management; urban agriculture; blue roofs; climate change

\section{Introduction}

Accommodating growing populations within urbanized areas is a difficult task due to the fact that most cities have already developed the available land. This creates an inherent pressure to optimize the amount of livable/usable space within a building, while still minimizing impact on the surrounding environment. There is increased interest for new buildings to utilize the technology of green roofs (GR) to provide a tangible economic and environmental return for both building owners and city communities as a whole. Although GRs are considered to have multiple benefits, one of the main drivers of the implementation of green roofs is to combat stormwater.

Green roofs have been used as stormwater management tools in Europe for decades, with widespread implementation originating in Germany in the late 1960s [1]. A properly constructed GR system serves two primary functions related to stormwater management; a GR can reduce the amount of stormwater runoff through its water retention capacity, as well as delay the peak flow of runoff, alleviating the pressures on stormwater infrastructures. These characteristics and effects of GR substrate layers and drainage materials have been extensively studied $[2,3]$. 
A portion of water that is retained in a GR is transferred into the atmosphere through evapotranspiration (ET) by the vegetation, and by evaporation from the soil surface, thus reducing the volume of water that flows to a city's Waste Water Treatment Plants (WWTP) [4]. Water retention and ET characteristics are affected by the storage capacities of a roof, the presence and amounts of soil and plants, and by the weather conditions and climate [5-8]. GRs with deeper soil or growing media, when used for the growth of food crops, are known as productive GRs. These GRs also have enhanced insulation values, reducing building energy consumption. Thus, GRs have the potential to address the water-energy-food (WEF) nexus, in which multiple benefits and sector interactions must be considered to effectively optimize designs [9].

\subsection{Sustainable Development and Green Roofs in Toronto}

Toronto has had a large impact on GR implementation in North America. A study at Ryerson University quantified the potential financial and environmental benefits of green roofs, which spurred the creation and adoption of a GR bylaw in 2009. This bylaw mandates implementation of GRs on buildings exceeding a certain gross floor area (GFA), and requires a minimum initial retention (abstraction) of rainfall of $5 \mathrm{~mm}$ [10]. Since the creation of this bylaw, multiple North American cities have adopted similar policies that utilize GR's as a stormwater management tool.

Due to the focus of the GR bylaws around an initial abstraction of rainfall, the majority of projects that are required to install a green roof adopt a bare minimum approach to these requirements. Synthetic growing media layers composed of woven fabrics, mineral wool or rock wool [11] instead of soil are often used. These layers focus on meeting the required water retention capacity while decreasing the added structural requirements for GRs, ultimately driving the short-term costs down. There is no regulation or validation that the systems are maintaining the required retention rates over their lifespan. Without proper assessment and regulation of the long-term stormwater performance of the GR, it is likely that these systems will not provide sustainable outcomes over the long run.

Considering the finite amount of roof space available within urban areas, GRs should be designed to maximize their environmental benefits and sustained effectiveness over their lifespan. Innovation within the GR industry such as the growth of vegetables, increased water retention and support of water harvesting practices should be included in updated policies.

\subsection{Green Roofs and Water}

Among the United Nations Sustainable Development Goals (UNSDG), Goal 6 is Clean Water and Sanitation. Over $40 \%$ of the world's population is affected by water scarcity, making water management techniques imperative.

GR systems could potentially retain and evaporate an average $60 \%$ of annual rainfall [12]. A blue roof void can also create substantial water retention benefit that can be utilized both under the GR and in hardscaping the area surrounding the vegetation [13].

Multiple studies on the ET of extensive green roofs have been conducted; most ET studies for GRs utilize lysimeters in isolated GR modules to determine changes in weight. The presence of small, drought-tolerant plants (such as sedums), has been determined to cause a maximum daily ET rate of $2.52 \mathrm{~mm} /$ day [13]. Green roof systems that utilize passive irrigation methods synergized with blue roof technology, such as through a wicking material between the water retention layer and the soil media, have shown increases in ET rates and overall retention capacities [14]. Increasing the amount of water available to the plants through capillary action resulted in an ET increase of 2 to $4 \mathrm{~mm}$, leading to higher plant productivity and a more effective building cooling rate [15]. This increase in ET also holds potential to reduce the carbon payback period of GR systems, by countering the embodied energy in the system materials with the reduced energy required for building cooling [16]. In the context of ET rates and vegetables, it has also been shown that an increase in soil depth results in higher ET rates [17]. These interactions between food and 
water and energy demonstrate the multi-faceted potential that green roofs hold to promote sustainability, to reduce the urban heat island helping to make cities livable, and to mitigate climate change.

An abundant amount of research encompasses the hydrological performance of extensive green roof systems [18-21]. However, there is an opportunity to research the effect that different drainage layers, soil depth, and vegetation types have on ET rates and an overall stormwater benefit. By establishing an array of blue, green and blue-green roof testbeds, this study aims to answer some of these questions. This research seeks to contribute knowledge on how enhancing the water balance of a GR can increase the environmental benefit of roofs in general.

\subsection{Green Roofs and Energy}

The UNSDG Goal 7 is Affordable and Clean Energy. Energy currently contributes approximately $60 \%$ of global greenhouse gas emissions.

The insulative properties and passive cooling capacities of soil-based GRs have an inherent benefit to reducing energy consumption in buildings [22]. Buildings with GRs experienced lower indoor temperatures in the summer and higher indoor temperatures in the winter in comparison to buildings with non-vegetated roofing assemblies [23]. Green roofs reduce energy consumption by altering the energy balance of buildings.

GRs also reduce energy expenditures within WWTPs. Treatment facilities for wastewater are often considered a major energy consumer within an urban area; 33\% of municipal energy consumption can be attributed to WWTP in the Greater Toronto Area (GTA) [24,25]. Reducing the amount of stormwater loading to a WWTP will ultimately result in less energy consumption particularly in cities like Toronto that utilize a combined sewer system.

Irrigation systems can also affect building energy consumption, as shown through thermal analysis of GRs [26,27]. As soil depth decreases, energy consumption during winter increases up to $140 \%$. Annually, energy use is affected by soil depth, vegetation height and leaf area index (LAI). In summer, a decrease in vegetation height and LAI increases energy use for cooling. For extensive GRs, there is a decrease in cooling energy requirement as irrigation flow rate increases.

The aim of this study is to investigate the WEF nexus through observing water balance variances across different GR types, which can reduce energy consumption while supporting food production.

\subsection{Green Roofs and Food Security}

Among the UNSDG, Goal 2 is Zero Hunger. Current estimates show $8.9 \%$ of the world's population experiencing hunger, with the numbers increasing over the past 5 years around the world. Local food production could contribute to mitigating these devastating conditions.

Despite the economic activity in Toronto, the city also holds refuge to large numbers of households that experience varying levels of food insecurity [28]. Urban agriculture is a growing sustainable trend that addresses food insecurity by decreasing the dependency that urbanized areas have on food systems outside of the city [29]. Green roofs have the capacity to support farming practices, as exhibited by the Ryerson Urban Farm (RUF), which generated $9000 \mathrm{lbs}$ of produce over the 2017 growing season [30]. Although a single rooftop farm does not have the productivity to eradicate food security issues for an entire city, it does have the capacity to alleviate some of the localized pressures on food demand. Multiple urban agriculture entrepreneurs and programs are now emerging in Toronto [31], including the Ryerson Urban Farm Living Lab [32], which will help to address questions related to farming management, job creation, and maintenance including planting, irrigation, harvesting, and soil optimization.

The current Toronto GR bylaw does not promote the inclusion of rooftop farming. This could be partly due to insufficient local data on the hydrological performance of rooftop farms. From a practical standpoint, maintenance approaches and structural limitations 
must be considered and optimized. In connection to the feasibility of GRs to produce vegetables, Stovin et al. [33] monitored the runoff retention of GR testbeds and showed that the testbeds with vegetation had better capacity to remove moisture. Deeper, vegetablesupporting GRs address the WEF nexus through increased water retention, enhanced insulative properties and urbanized food production.

\section{Materials and Methods}

The GR systems in this study consisted of an extensive GR (4" growing media), an extensive GR combined with a blue roof (BR) spacer, and two rooftop farm plots growing various vegetables. The primary objective of this study is to determine the enhancement of green roof water retention and evapotranspiration (ET) rates through different submedia drainage systems, and how these systems can address the WEF nexus.

\subsection{Overview of Lab Layout}

Five testbed modules were constructed on the rooftop of a building within the downtown core of Toronto, Canada. The property is a three-storey combined office and residential building with a conventional flat roof approved and built to accommodate the structural capacities of a GR. The main characteristics of each module are summarized in Table 1.

Table 1. Test module characteristics.

\begin{tabular}{lccccc}
\hline & Extensive (P1) & Extensive + Blue (P2) & Aggregate (P3) & Productive (P4) & Productive + Blue (P5) \\
\hline $\begin{array}{l}\text { Media } \\
\text { Drainage Device }\end{array}$ & $\begin{array}{c}\text { Extensive Blend } \\
\text { Drainage Board } \\
\text { Plant Material }\end{array}$ & $\begin{array}{c}\text { Extensive Blend } \\
\text { Blue Roof } \\
\text { Sedums }\end{array}$ & $\begin{array}{c}\text { Dolomite } \\
\text { Drainage Board } \\
\text { None }\end{array}$ & $\begin{array}{c}\text { Farm Blend } \\
\text { Drainage Board } \\
\text { Carrot-Beet rotation; } \\
\text { clover cover crop }\end{array}$ & $\begin{array}{c}\text { Farm Blend } \\
\text { Blue Roof } \\
\text { Carrot-Beet rotation; } \\
\text { winter rye cover crop }\end{array}$ \\
\hline $\begin{array}{l}\text { Media Depth } \\
\text { Total System Depth }\end{array}$ & $100 \mathrm{~mm}$ & $100 \mathrm{~mm}$ & $25+55 \mathrm{~mm}$ infill & $175 \mathrm{~mm}$ & $175 \mathrm{~mm}$ \\
\hline Drainage Retention & $8 \mathrm{~mm}$ & $170 \mathrm{~mm}$ & $90 \mathrm{~mm}$ & $11 \mathrm{~mm}$ & $240 \mathrm{~mm}$ \\
Media Retention & $35 \mathrm{~mm}$ & $50 \mathrm{~mm}$ & $0 \mathrm{~mm}$ & $79 \mathrm{~mm}$ & $50 \mathrm{~mm}$ \\
Total Retention & $43 \mathrm{~mm}$ & $35 \mathrm{~mm}$ & $18 \mathrm{~mm}$ & $239 \mathrm{mg} / \mathrm{m}^{2}$ & $129 \mathrm{~mm}$ \\
\hline Saturated Mass & $128 \mathrm{~kg} / \mathrm{m}^{2}$ & $175 \mathrm{~kg} / \mathrm{m}^{2}$ & $115 \mathrm{~kg} / \mathrm{m}^{2}$ & $278 \mathrm{~kg} / \mathrm{m}^{2}$ \\
\hline
\end{tabular}

The test modules were constructed with a footprint of $0.72 \mathrm{~m}^{2}(1.2 \mathrm{~m} \times 0.6 \mathrm{~m})$ each and simulate higher slopes associated with typical flat roofs $(4 \%)$. The dimensions of the testbeds were designed to support a drainage reservoir underneath that has the storage capacity of $50 \mathrm{~L}$; otherwise considered as the equivalent to $67 \mathrm{~mm}$ of runoff from rain events. Each of the testbeds utilize GR-growing media that follow the FLL guidelines, including a porosity of $60 \%$ and an averaged density of $850 \mathrm{~kg} / \mathrm{m}^{3}$ [17]. This was to establish evapotranspiration and retention rates that can be correlated to multiple GR systems that are currently being sold in the marketplace.

Two of the modules are planted with typical GR vegetation composed of droughttolerant succulents (sedums) to mimic typical industry practice for an extensive GR. To determine contrasting water balances provided by vegetable production, two of the modules are "productive" plots and consist of vegetable plantings. A fifth control module utilizes a $60 \mathrm{~mm}$ blue roof spacer with crushed white dolomite to simulate an area of a rooftop that does not sustain vegetation; under the current green roof construction guidelines there is a $500 \mathrm{~mm}$ wide vegetation-free zone around the perimeter of green roofs [34]. The layers of the modules are described below in Table 1, with corresponding water retention specifications.

Test module $\mathrm{P} 1$ is considered as the base control group as the industry standard extensive GR. This system includes water retention in both a base protection layer $(5 \mathrm{~mm})$ and a three-dimensional drainage layer $(25 \mathrm{~mm})$. On top of these water retention capacities, $100 \mathrm{~mm}$ of extensive growing media provides additional water retention. Plug planted sedums, which come in a tray of 72 plants were planted at approximately 25 plants per $\mathrm{m}^{2}$. 
This system, commonly used amongst various green roof suppliers, meets green roof construction standards [35].

Test module P2 is similar to P1 with respect to growing media depth and vegetation but has a contrasting water retention system, as shown in Figure 1. A blue roof (BR) storage void of $65 \mathrm{~mm}$, creates a water retention capacity beneath the growing media, separated by a filter sheet to keep the growing media out of the sublayer. Green roofs combined with BR voids are a growing submarket within the GR industry. The benefits of this type of system are an extensive GR with minimal structural requirements compared to greater soil depths, but a maximized amount of water retained within the system. Previous research conducted in the Netherlands concluded that the additional water retention provided by BR voids contributes to higher ET rates and thus increased mitigation of the urban heat island [14].

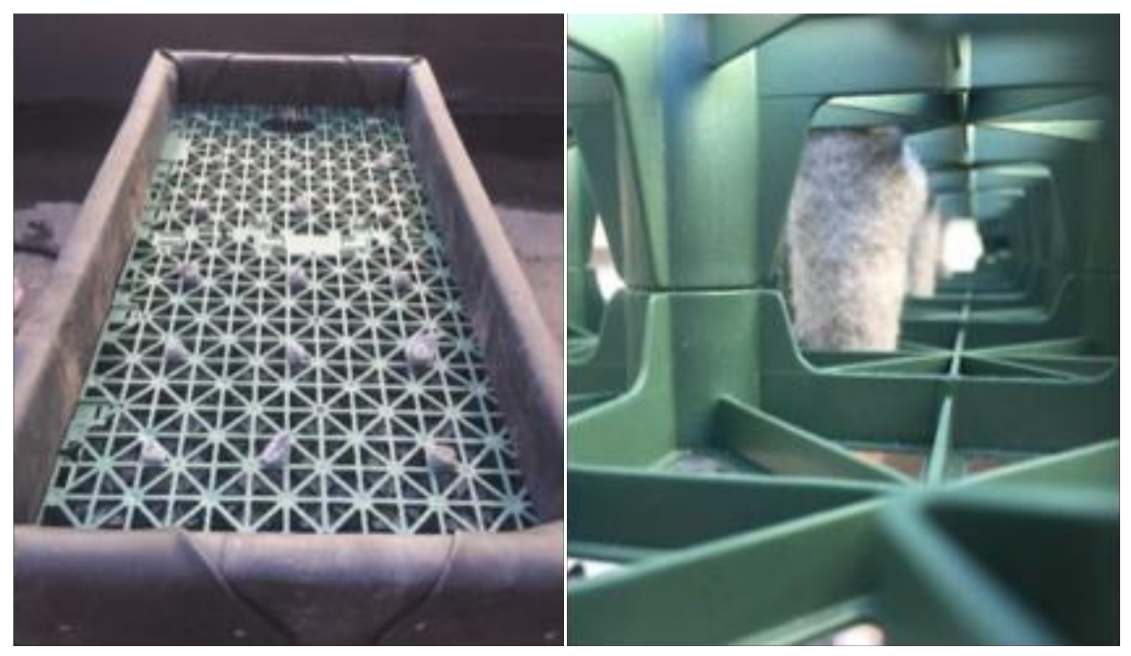

Figure 1. Extensive GR module P2 blue roof sublayer with capillary wicking elements.

The third test module (P3) uses a BR spacer under crushed dolomite, as shown in Figure 2; this aggregate is typically used in construction materials and is mined across several locations within Ontario [36].

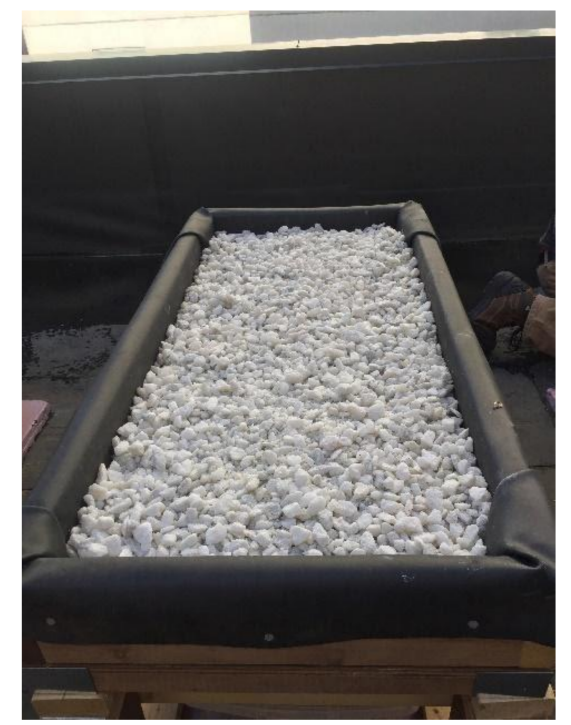

Figure 2. White dolomite aggregate in module P3.

Test module $\mathrm{P} 4$ is considered the baseline productive control group utilizing vegetables in place of the traditional sedum vegetation used in GRs in Toronto. This assembly includes $200 \mathrm{~mm}$ of growing media, on top of a $40 \mathrm{~mm}$ drainage board with an increased retention 
capacity; this is the suggested system buildup provided to support vegetable production on roofs [37]. The system buildup employs a "Wicking Mat" that utilizes capillary action to increase the distribution of submedia water retention and to increase the ET rates of the green roof plants [38]. A key effect of the capillary methods of increasing moisture in the system is potentially less demand on traditional irrigation systems. Although the media blend satisfies FLL requirements, there is an increased percentage of organic matter in this blend in order to sustain life for the vegetables [39]. Multiple species of produce will be harvested from this module to simulate crop rotations of the Ryerson Urban Farm, located a few blocks away. Based on the increased growing media and retention system depth, it is hypothesized that there will be a clear enhancement of the retention capacity of this system. This information is important for future policy decisions made by cities and could motivate decision makers to incentive rooftop farms rather than sedum-based GRs.

The final test module (P5), shown with P4 in Figure 3, is also defined as a productive module that supports vegetable production. The P5 system utilizes a deeper blue roof retention layer.

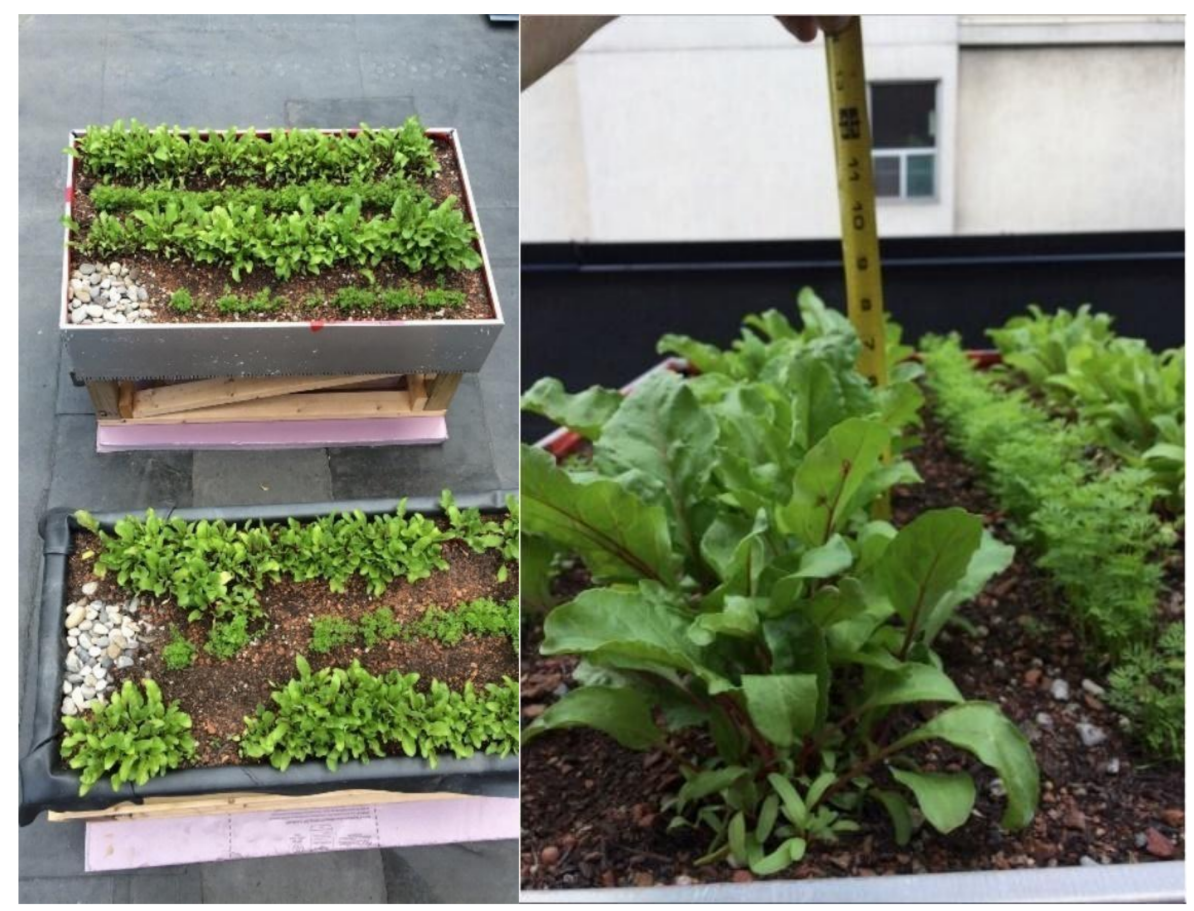

Figure 3. Modules P4 and P5 showing beet and carrot plant growth.

\subsection{Description of Lysimeter System}

External drainage reservoirs for each of the modules collect the water that flows out of the system, as shown in Figure 4. To establish the retention capacities of the test modules and the associated ET rates, a lysimeter was implemented. Digital load cells were utilized under the four corners of the bed to measure weight to obtain the mass transfer of water in the modules; there were also 3 loads cells measuring the weight of the drainage reservoir in order to determine how much rainfall was not retained in the module. Between these seven sensors the water flow in and out of the modules can be obtained, isolating ET as differences in mass transfer. The data from the load cells were obtained by a Pi Zero microcomputer, combined with an 8-channel multiplexer to provide communication for all cells on the same i2c bus [40]. To mitigate the risks of water damage, all electronics were contained within a PVC conduit assembly. The lysimeter system with the testbed assembly is shown in Figure 4. 


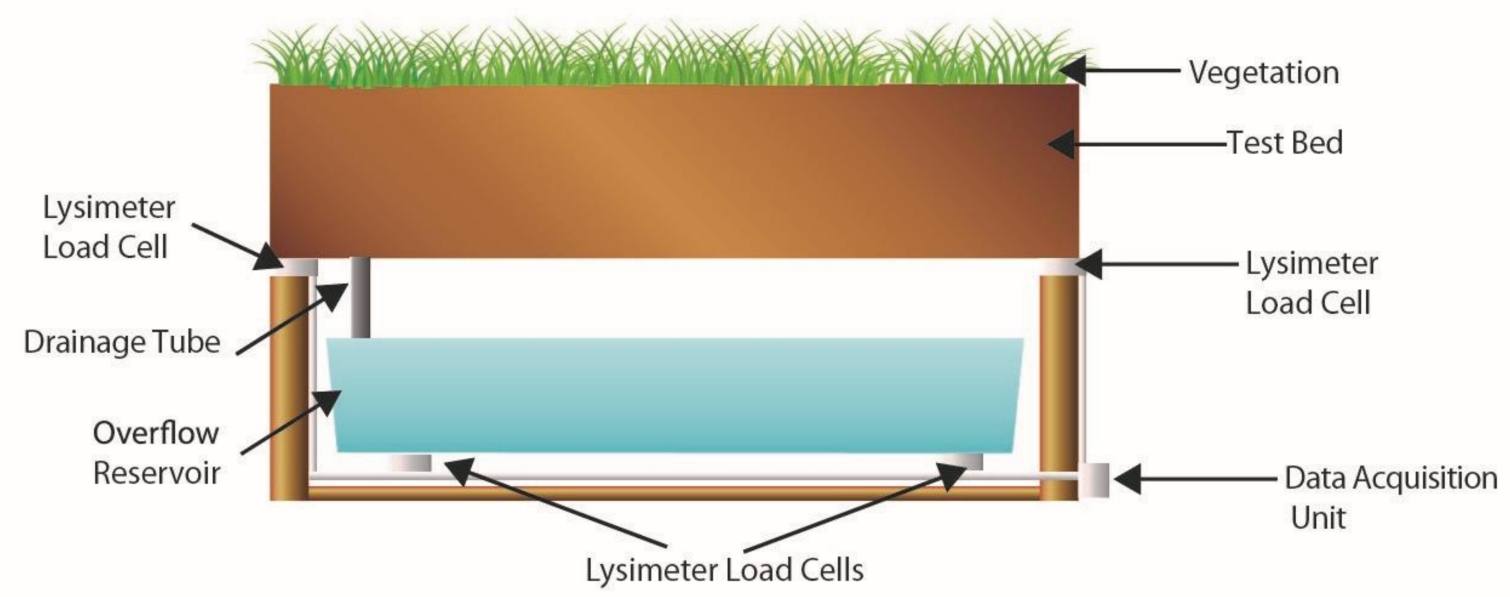

Figure 4. Overflow reservoir and lysimeter system to monitor the hydrological behaviour of the green roof testbed.

\subsection{Description of Data Acquisition}

All data were transferred via the building's WiFi to the Google cloud platform, allowing for remote access of information, partly due to the location of the lab as well as the SARS-CoV-2 pandemic restricting onsite presence. All data were organized into an SQL database enabling adaptable analysis [40].

\section{Results}

\subsection{Stormwater Retention}

Since installation, there has been minimal irrigation provided to the plants in the extensive modules. This is to build up the species resilience in the microclimate, as well as to simulate a typical extensive GR implementation which generally does not include irrigation.

Figure 5 shows the amount of overflow measured in each of the drainage reservoirs after three successive rainfall events. The water levels were measured in $\mathrm{mm}$ in the translucent containers, and the reservoirs were emptied after each measurement. As can be seen, the extensive module $\mathrm{P} 1$ and the BR aggregate module $\mathrm{P} 3$ show stormwater runoff, with other modules having no runoff at all after the first two (moderate) rainfall events. The 7th of August reflects a rare rain event with massive thunderstorms occurring in the two days prior to the visit to the rooftop. Upon inspection, the drainage reservoir under the P3 module was filled to the rim, with the lid floating on top-as the container had been forced open. Ultimately, the only number that can be used to reflect this overflow is the height of the bin, $152 \mathrm{~mm}$, though it was abundantly clear that much more rainfall than this had passed through the non-GR dolomite module P3. After this heavy storm event, productive module P5 still had zero runoff. 


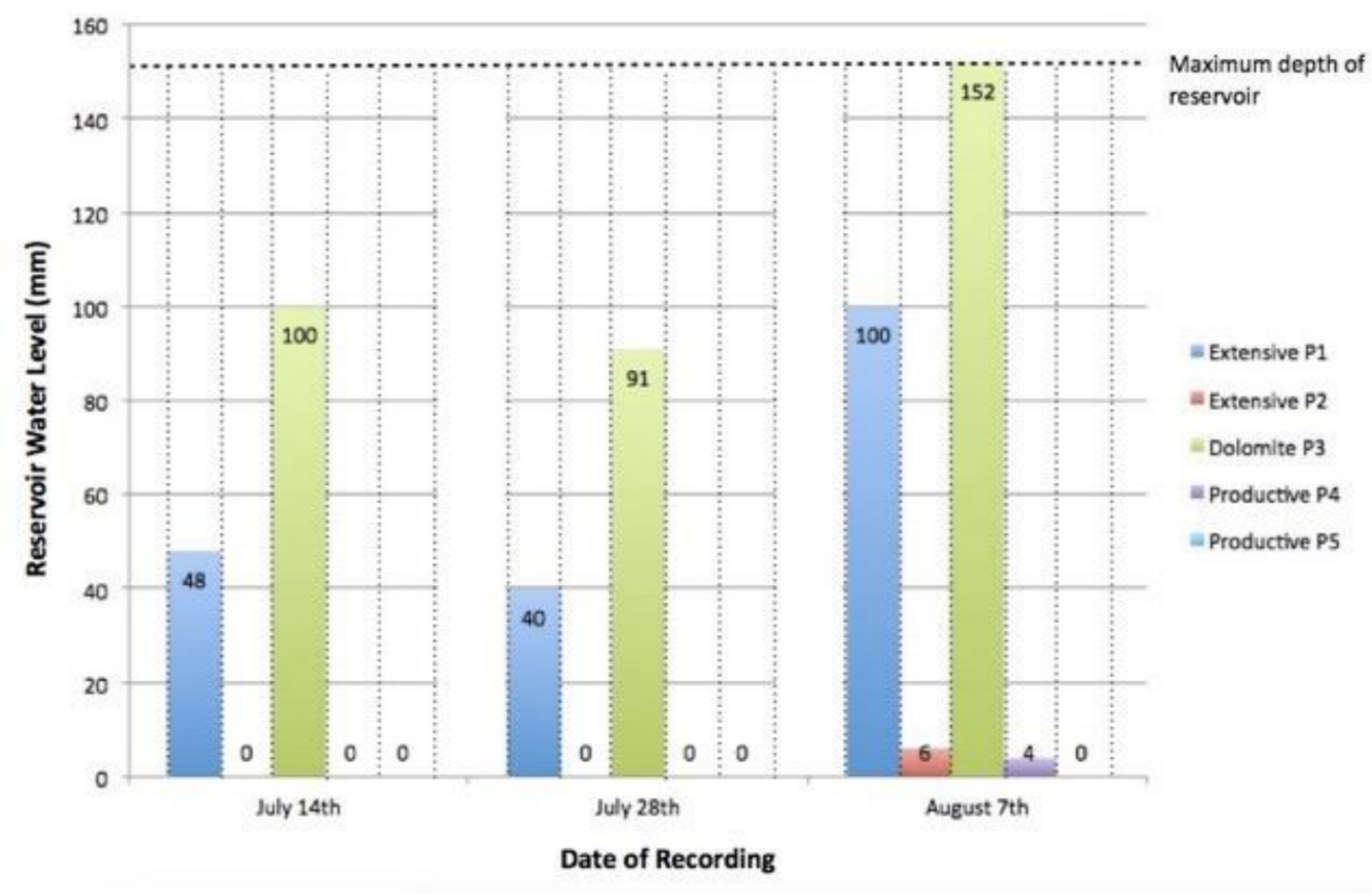

Figure 5. Water levels in the drainage reservoirs reflecting runoff measures over three separate rainfall events in modules P1-P5.

Lysimeter loading data from September, 2020 are presented in Figure 6 across daily intervals for the P1 extensive plot; the net mass includes gains from rainfall and losses from ET. From this daily average dataset it can be observed, for example, that after rainfall on day 9 ET slowly declined as a function of reduced available moisture content in the growing media as expected. From these data, the ET rate of the P1 module averaged $2.27 \mathrm{~mm} /$ day, with a maximum of $4.42 \mathrm{~mm}$ measured on September 15th, as reported previously by our team [40].

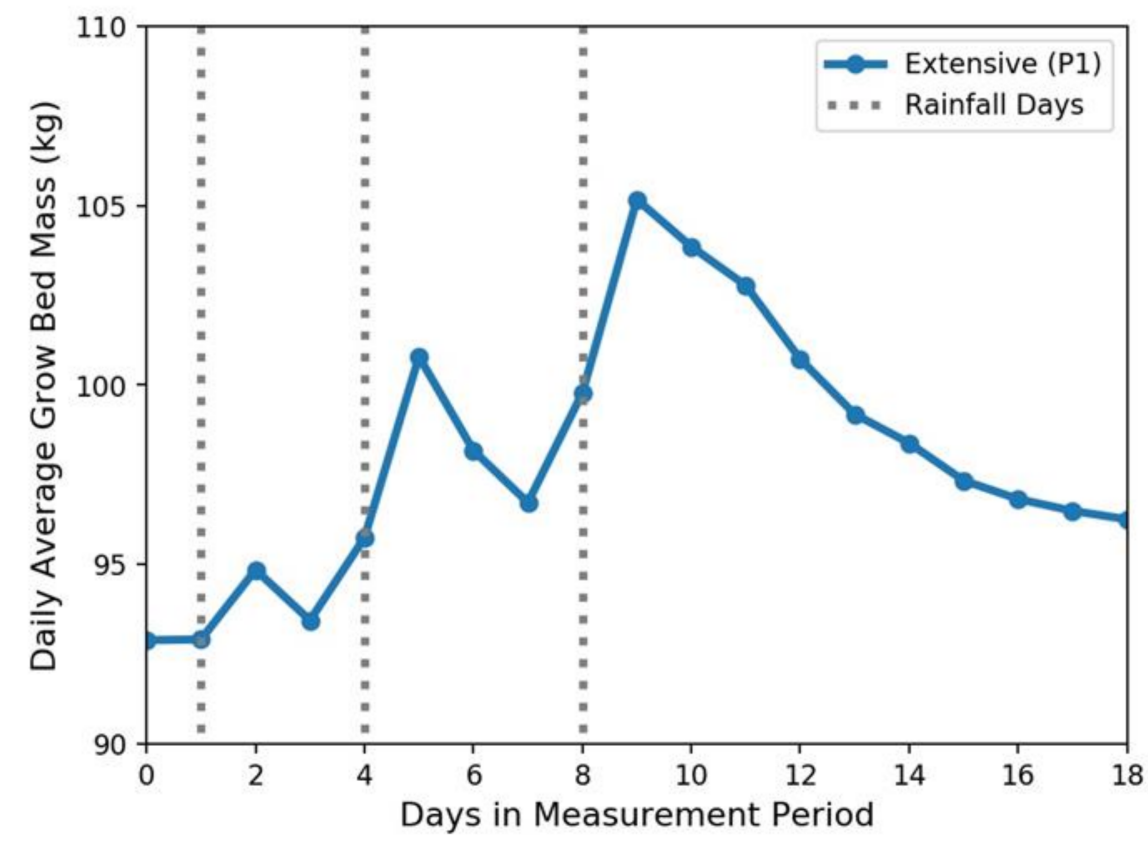

Figure 6. Extensive grow bed P1 mass changes resulting from rainfall and evapotranspiration. 


\subsection{Agricultural Productivity}

Each productive module (P4 and P5) was planted with alternating rows of carrots and beets in two identical crop rotations. Growth was charted by measuring the height of several plants on each measurement day and taking the average. The growth curves of the two harvest cycles over a period of 2.5 months can be seen in Figure 7.

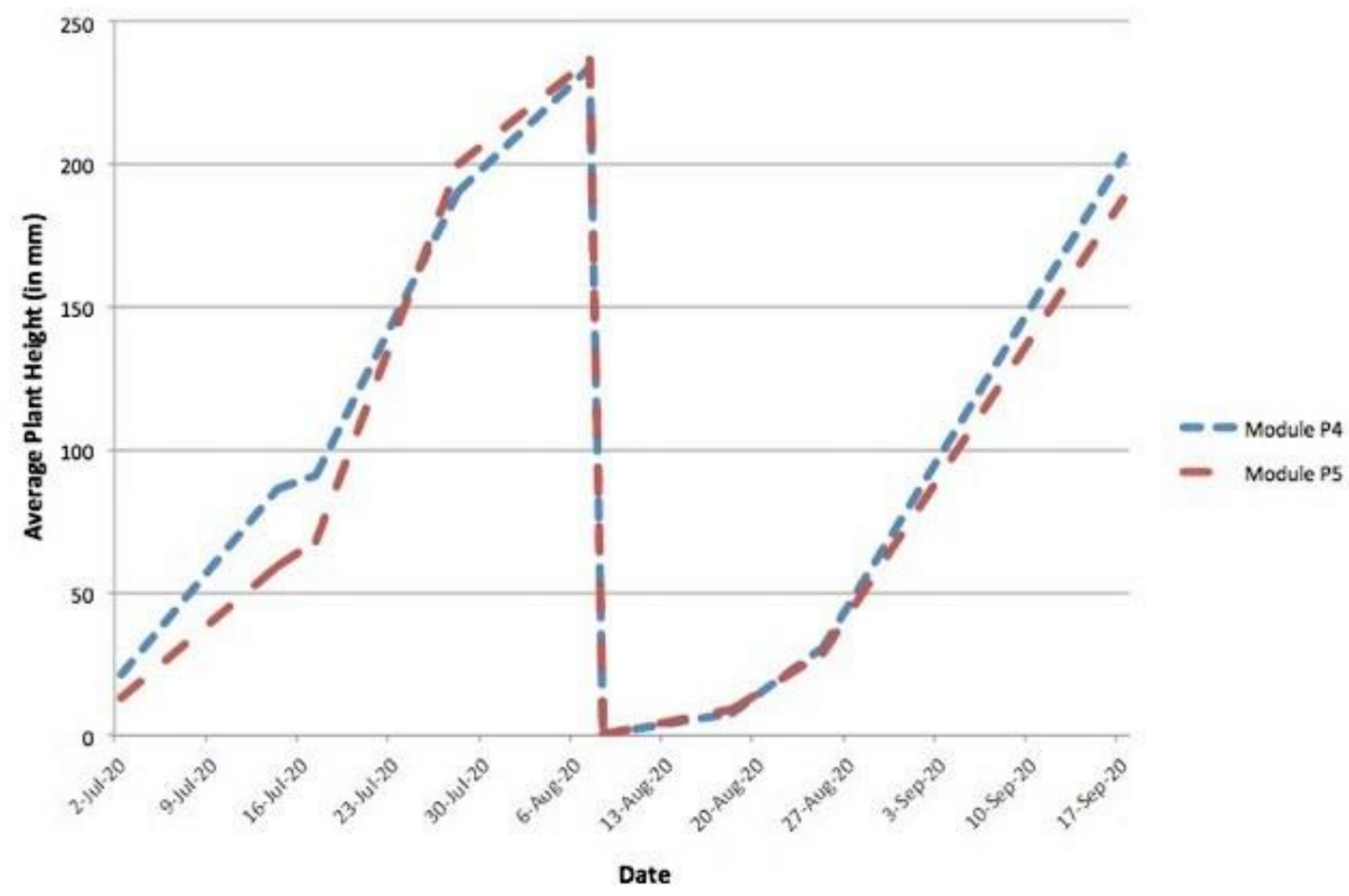

Figure 7. Height of vegetable plant in productive modules P4 and P5 over two harvest cycles.

\section{Discussion}

The modules presented in this work provide the ability to test a wide range of GR systems for optimization of WEF-related factors. They can provide quantifiable patterns and levels of response in key variables (e.g., stormwater storage/retention/runoff, ET, and growth/productivity).

The urban agriculture productive test modules P4 and P5 demonstrated zero and almost zero overflow during three consecutive rain events. This demonstrates the potential for green roof urban agriculture as a tool for stormwater management as well as food production and energy use reduction (through the reduced load on municipal WWTPs and through reduced building cooling requirements in summer resulting from increased ET). In addition, the urban agriculture modules produced two harvests of hyper-local food contributing to reduced food transportation. These two productive test modules totaled only approximately $1.5 \mathrm{~m}^{2}$ of growing area, and need to be scaled up to achieve a meaningful contribution to the population food requirements.

The preliminary results of the ET rates of the P1 extensive green roof module obtained from the lysimeter load cell data are similar to other ET research on sedum-based roofs found during the literature review [41]. It is anticipated that the productive modules will yield similar results to the study performed by Whittinghill et al. while having a higher ET rate compared to the sedum roofs [42]. The potential for productive GRsto exhibit higher retention and ET rates was observed in productive modules P4 and P5, which had almost zero overflow, and demonstrated high-level stormwater management. However, additional studies are required to validate stormwater management and ET on larger scales. 
Using the blue roof test modules to determine the overall water balance of systems that harvest water (P2 and P3) could also hold the opportunity to influence future green roof policies in cities such as Toronto. The research to date describes the benefit of utilizing ponding elements on drains underneath green roofs in synergy with blue roof voids. The results can be seen directly in the way that module P2 had minimal runoff when compared to $\mathrm{P} 1$. This demonstrates the benefit of adding retention sublayers under conventional extensive green roofs for stormwater management. Even with its comparably high volumes of runoff, the aggregate blue roof system holds value to existing rooftops that may not have the capacity to support a vegetated assembly but can still mitigate the effects of stormwater runoff. The preliminary results of the manually measured runoff volumes in the water reservoirs do support the hypothesis that roofs with deeper retention systems and deeper growing media will result in decreased runoff. The addition of porous growing media and living plants to urban surfaces allows rainwater to be absorbed and evaporated locally, limiting the load on city infrastructure.

Enhanced ET could be provided by the vegetables compared to the sedum vegetation. Additional load cell data will be needed to compare the profile of P2 to the productive modules P4 and P5, and to evaluate trade-offs with structural, maintenance and cost factors. There is a strong correlation between our demand for food, energy and water and overall demand is increasing. The relationship of how the domains of water, energy and food interact is often described as a nexus [43]. As the demand for both food and energy trends upwards, so does the requirement for water within these systems [44].

Urban agriculture also reduces the carbon footprint of food supply chains by decreasing the distance traveled for produce [45]. From the economic aspect, there is a positive Net Present Value (NPV) when there is a short food supply chain on GR production [46]. Despite a limited growing season, there is additional savings in energy through the insulation value produced by plant ET. Thus, productive GRs will help reduce energy consumption and increase food security.

GRs are effective tools to manage stormwater [47] and this research provides insight on how these tools can be enhanced to address stormwater better while decreasing energy consumption and producing food. Though an extensive GR can also support vegetable growth [42], a green roof with deeper growing media will be more effective in addressing the WEF.

With rooftop real estate a finite resource in urban areas, environmental considerations warrant consideration of its use for renewable energy systems. This appears to compete with GRs, however, synergistic effects have also been shown. In a study of agrivoltaics, the co-location of solar photovoltaics and agriculture demonstrated that soil areas shaded by PV panels retained $15 \%$ excess moisture content, which supported enhanced fruit production in tomato and chiltepin peppers compared to the unshaded control [48]. Dupraz et al. showed a $35-73 \%$ increase in overall land productivity when strategically combining photovoltaics and agriculture [49]. These results are consistent with those of Dinesh and Pearce, who calculated over $30 \%$ in additional economic value to farm operators [50]. Green roofs provide the foundation for agrivoltaic systems to proliferate in the urban context as a solution to the WEF nexus.

This study presents customizable testbeds for quantitative evaluation of WEF nexus variables. Understanding the enhanced water retention capacities of submedia drainage layers will motivate more GR projects to incorporate systems that support the production of vegetables, decrease the amount of energy consumed in WWTPs, and decrease the amount of water needed to sustain GR vegetation. This research also supports multiple aspects of the United Nations Sustainable Development Goals, including Goal 2: Zero Hunger, Goal 6: Clean Water, and Goal 7: Affordable and Clean Energy [51].

\section{Future Work}

Further research activities for the rooftop lab are planned. These include rainwater harvesting and overflow water re-use for irrigation purposes. Soil and overflow water 
quality testing will be performed. Importantly, more data will be collected to improve the reliability of the findings. Replicated modules, soil moisture and vapour pressure measurement, and lysimeters for all modules will be added. A new, more accurate weather and camera station for real-time rainfall and local temperature data is also planned.

Further research on the associated effects of submedia drainage layers should include the effect of ET rates on plant productivity, nutrient runoffs, delayed peak flows, etc. Our study suggests an associated stormwater benefit from green roofs with larger storage reservoirs or more productive plants, versus traditional setups such as module P1 or P3. A second full growing season will provide more insight into the long-term water balance metrics of the various subdrainage assemblies, which will be beneficial to city policy makers and persons within the local GR industry.

This research suggests that the ET and retention of green roof systems is affected by the interval and magnitude of rainfalls, which in turn promotes the use of systems that have larger submedia drainage reservoirs. The expectation is that using a system with a larger submedia drainage layer will enhance the performance and resilience of green roofs. Focusing on increasing the resilience and environmental benefit of green roof systems is increasingly important given climate change impacts. This is why harnessing knowledge on how to go above and beyond the current practices will motivate necessary innovation within the green roof industry.

Author Contributions: All authors (J.W., J.L., D.S., L.M., and K.V.M.) contributed equally to the conceptualization and methodology. J.W., with inputs from the other authors, prepared the original draft writing, and all authors contributed to editing and review of the writing. All authors contributed to development, data curation, validation and resources. K.V.M. supervised and administered the work. All authors have approved the published version of this manuscript.

Funding: J.W., J.L, D.S., L.M., and K.V.M. acknowledge the support of the Ryerson Urban Farm Living Lab through the Ryerson Urban Farm operations and the financial support of Andrew and Valerie Pringle, and the support from the Environmental Applied Science and Management Program at Ryerson University.

Acknowledgments: J.W., J.L, D.S., L.M., and K.V.M. acknowledge the support of Adam Johnstone in facilitating the research, Laura Minkowski for her inputs and advice, Arlene Throness, Jayne Miles and Sharene Shafie from the Ryerson Urban Farm for their collaboration and advice, Fiona Yeudall at the Centre for Studies in Food Security at Ryerson University and Andrew Laursen at the Environmental Applied Science and Management Program at Ryerson University for their support, and Tom Hinckley for his recommendations on this manuscript.

Conflicts of Interest: Jeremy Wright is employed in the Green Roof sector by ZinCo Canada. The funders had no role in the design of the study, in the collection, analysis, or interpretation of data, in the writing of this manuscript, or in the decision to publish the results.

\section{References}

1. Magill, J.D.; Midden, K.; Groninger, J.; Therrell, M. A History and Definition of Green Roof Technology with Recommendations for Future Research; Research Papers; Southern Illinois University: Carbondale, IL, USA, 2011; Available online: http:/ / opensiuc.lib. siu.edu/gs_rp/91 (accessed on 9 September 2020).

2. Baryła, A.; Karczmarczyk, A.; Brandyk, A.; Bus, A. The influence of a green roof drainage layer on retention capacity and leakage quality. Water Sci. Technol. 2018, 77, 2886-2895. [CrossRef]

3. Baryła, A.M. Role of drainage layer on green roofs in limiting the runoff of rainwater from urbanized areas. J. Water L. Dev. 2019, 41, 12-18. [CrossRef]

4. Banting, D.; Doshi, H.; Li, J.; Missios, P.; Au, A.; Currie, B.A.; Verrati, M. Report on the Environmental Benefits and Costs of Green Roof Technology for the City of Toronto; City of Toronto and Ontario Centres of Excellence: Toronto, ON, Canada, 2005.

5. Johannessen, B.G.; Hanslin, H.M.; Muthanna, T.M. Green roof performance potential in cold and wet regions. Ecol. Eng. 2017, 106, 436-447. [CrossRef]

6. Viola, F.; Hellies, M.; Deidda, R. Retention performance of green roofs in representative climates worldwide. J. Hydrol. 2017, 553, 763-772. [CrossRef]

7. Ebrahimian, A.; Wadzuk, B.; Traver, R. Evapotranspiration in Green Stormwater Infrastructure Systems. Sci. Total Environ. 2019, 688, 797-810. [CrossRef] 
8. Hill, J.C.; Drake, J.; Sleep, B.; Margolis, L. Influences of Four Extensive Green Roof Design Variables on Stormwater Hydrology. J. Hydrol. Eng. 2017, 22, 04017019. [CrossRef]

9. Cristiano, E.; Deidda, R.; Viola, F. The role of green roofs in urban Water-Energy-Food-Ecosystem nexus: A review. Sci. Total. Environ. 2021, 756, 143876. [CrossRef] [PubMed]

10. City of Toronto Municipal Government. City of Toronto Green Roof Bylaw. 13 November 2020. Available online: https://www. toronto.ca/city-government/planning-development/official-plan-guidelines/green-roofs/green-roof-bylaw / (accessed on 9 September 2020).

11. Breuning, J. What Is Mineral Wool? 16 September 2014. Available online: http://www.greenrooftechnology.com/Mineral\%20 Wool\%20in\%20Green\%20Roofs / mineral-wool-in-green-roofs (accessed on 14 September 2020).

12. Hammond, R. Evaluating Green and Blue Roof Opportunities in Canadian Cities. Master's thesis, University of Waterloo, Waterloo, AN, Canada, 2017.

13. Feng, Y.; Burian, S.J.; Pardyjak, E.R. Observation and Estimation of Evapotranspiration from an Irrigated Green Roof in a Rain-Scarce Environment. Water 2018, 10, 262. [CrossRef]

14. Cirkel, D.; Voortman, B.R.; Van Veen, T.; Bartholomeus, R.P. Evaporation from (Blue-)Green Roofs: Assessing the Benefits of a Storage and Capillary Irrigation System Based on Measurements and Modeling. Water 2018, 10, 1253. [CrossRef]

15. Jauch, M.; Krummradt, I.; Schmitz, H.J.; Lohr, D.; Meinken, E. Optimization of Evapotranspiration and Cooling Capacity of Extensive Green Roofs Through Targeted Use of Gray Water; Hochschule Weihenstephan-Triesdorf Univerisity of Applied Sciences: Freisen, Germany, 2016.

16. Auld, D.; Wright, J. Carbon Sequestering and Green Roof Technology: A Benefit Cost Analysis. Environ. Manag. Sustain. Dev. 2018, 7, 85-92. [CrossRef]

17. Ono, K.; Yanagi, M.; Kudo, T.; Teshirogi, J.; Shibuya, Y.; Koshimizu, H. Evapotranspiration Rate of Rooftop Gardening Plants. J. Jpn. Soc. Reveg. Technol. 2005, 32, 74-79. [CrossRef]

18. Berndtsson, J.C. Green roof performance towards management of runoff water quantity and quality: Review. Ecol. Eng. 2010, 36, 351-360. [CrossRef]

19. DiGiovanni, K.; Gaffin, S.; Montalto, F. Green Roof Hydrology: Results from a Small-Scale Lysimeter Setup (Bronx, NY). Low Impact Dev. 2010, 1, 1324-1328.

20. Moran, A.C.; Hunt, W.F.; Smith, J.T. Green roof hydrologic and water quality performance from two field sites in North Carolina. In Managing Watersheds for Human and Natural Impacts; American Society of Civil Engineers: Williamsburg, VA, USA, 2005; pp. 1-12.

21. VanWoert, N.D.; Rowe, D.B.; Andresen, J.A.; Rugh, C.L.; Fernandez, R.T.; Xiao, L. Green roof stormwater retention: Effects of roof surface, slope, and media depth. J. Environ. Qual. 2005, 34, 1036-1044. [CrossRef]

22. Castleton, H.; Stovin, V.; Beck, S.; Davison, J. Green roofs; building energy savings and the potential for retrofit. Energy Build. 2010, 42, 1582-1591. [CrossRef]

23. La Roche, P.; Berardi, U. Comfort and energy savings with active green roofs. Energy Build. 2014, 82, 492-504. [CrossRef]

24. Capodaglio, A.G.; Olsson, G. Energy Issues in Sustainable Urban Wastewater Management: Use, Demand Reduction and Recovery in the Urban Water Cycle. Sustainability 2019, 12, 266. [CrossRef]

25. Environmental Commissioner of Ontario. Every Drop Counts, Reducing the Energy and Climate Footprint of Ontario's Water Use, Annual Energy Conservation Progress Report, vol. 1, 2016-2017. Available online: https://www.auditor.on.ca/en/content/ reporttopics/envreports/env17/Every-Drop-Counts.pdf (accessed on 20 October 2020).

26. Sun, T.; Bou-Zeid, E.; Ni, G.-H. To irrigate or not to irrigate: Analysis of green roof performance via a vertically-resolved hygrothermal model. Build. Environ. 2014, 73, 127-137. [CrossRef]

27. Gomes, S.; Valadas, S. Impact of Vegetation, Substrate, and Irrigation on the Energy Performance of Green Roofs in a Mediterranean Climate. Water 2019, 11, 2016. [CrossRef]

28. Paul, C.; John, G.; Barbara, E.; Marianne, G.; Heather, O.; Coleman, P.; Gultig, J.; Emanuel, B.; Gee, M.; Orpana, H. Status report-FoodReach Toronto: Lowering food costs for social agencies and community groups. In Health Promotion and Chronic Disease Prevention in Canada; Public Health Agency of Canada: Ottawa, ON, Canada, 2018; Volume 38, pp. 23-28.

29. Miernicki, E.A.; Lovell, S.T.; Wortman, S.E. Raised Beds for Vegetable Production in Urban Agriculture. Urban Agric. 2018, 3, 180002. [CrossRef]

30. Ryerson Urban Farm. Highlights of the Urban Farm's Growing Seasons; Ryerson University: Toronto, ON, Canada, 2020; Available online: https: / / www.ryerson.ca/university-business-services/urban-farm/ (accessed on 20 October 2020).

31. Zawadi Farm Toronto ON. 2020. Available online: https:/ / zawadi.farm/ (accessed on 21 October 2020).

32. Ryerson Urban Farm Living Lab, Ryerson University Toronto ON. 2021. Available online: https: / /www.ryerson.ca/foodsecurity/ projects/activity_urban_Farm_living_lab/ (accessed on 21 October 2020).

33. Stovin, V.; Poë, S.; De-Ville, S.; Berretta, C. The influence of substrate and vegetation configuration on green roof hydrological performance. Ecol. Eng. 2015, 85, 159-172. [CrossRef]

34. Editorial Board Green Roofs. Green Roof Guidelines-Guidelines for the Planning, Construction and Maintenance of Green Roofs. In Landscape Development and Landscaping Research Society; Green Roof Technology: Bonn, Germany, 2018.

35. Toronto Green Roof Technical Advisory Group. Toronto Green Roof Construction Standard Supplementary Guidelines; Toronto Green Roof Technical Advisory Group: Toronto, ON, Canada, 2010. 
36. Mackinnon, A.; Lebaron, P. Precambrian Dolomite Resources in Southeastern Ontario; Ministry of Northern Development and Mines: Toronto, ON, Canada, 1990.

37. ZinCo Canada Inc. Urban Farming Roof 2020. Available online: https://www.zinco.ca/green-roof-systems/urban-farming (accessed on 21 October 2020).

38. ZinCo Inc. Product Data Sheet Wicking Mat DV 40. 2020. Available online: https://www.zinco.ca/assets/pdf/ZinCo_PDB_ Wicking_Mat_DV40_engl.pdf (accessed on 21 October 2020).

39. ZinCo Canada Inc. Growing Media. 2020. Available online: https://www.zinco.ca/reference-library/component-detail/ growing-media (accessed on 3 November 2020).

40. Lytle, J.; Santillo, D.; Mai, K.V.; Wright, J. Remote Monitoring of Evapotranspiration from Green Roof Systems. In Proceedings of the 11th IEEE Annual Ubiquitous Computing, Electronics \& Mobile Communication Conference (UEMCON), New York, NY, USA, 10-12 October 2020.

41. Metselaar, K. Water retention and evapotranspiration of green roofs and possible natural vegetation types. Resour. Conserv. Recycl. 2012, 64, 49-55. [CrossRef]

42. Whittinghill, L.; Rowe, B.; Andresen, J.; Cregg, B. Comparison of Stormwater Runoff From Sedum, Native Prarie and Vegetable Producing Green Roofs. Urban Ecosyst. 2015, 18, 13-29. [CrossRef]

43. D'Odorico, P.; Davis, K.F.; Rosa, L.; Carr, J.A.; Chiarelli, D.; Dell'Angelo, J.; Gephart, J.; MacDonald, G.K.; Seekell, D.A.; Suweis, S.; et al. The Gobal Food-Energy-Water Nexus. Rev. Geophys. 2018, 56, 456-531. [CrossRef]

44. United Nations. UN Water: Water, Food and Energy. 2020. Available online: https://www.unwater.org/water-facts/water-foodand-energy/ (accessed on 28 November 2020).

45. Goldstein, B.; Hauschild, M.; Fernández, J.E.; Birkved, M. Contributions of Local Farming to Urban Sustainability in the Northeast United States. Environ. Sci. Technol. 2017, 51, 7340-7349. [CrossRef]

46. Benis, K.; Turan, I.; Reinhart, C.; Ferrão, P. Putting rooftops to use-A Cost-Benefit Analysis of food production vs. energy generation under Mediterranean climates. Cities 2018, 78, 166-179. [CrossRef]

47. Qin, Y. Urban Flooding Mitigation Techniques: A Systematic Review and Future Studies. Water 2020, 12, 3579. [CrossRef]

48. Barron-Gafford, G.A.; Pavao-Zuckerman, M.A.; Minor, R.L.; Sutter, L.F.; Barnett-Moreno, I.; Blackett, D.T.; Thompson, M.; Dimond, K.; Gerlak, A.K.; Nabhan, G.P.; et al. Agrivoltaics provide mutual benefits across the food-energy-water nexus in drylands. Nat. Sustain. 2019, 2, 848-855. [CrossRef]

49. Dupraz, C.; Marrou, H.; Talbot, G.; Dufour, L.; Nogier, A.; Ferard, Y. Combining solar photovoltaic panels and food crops for optimising land use: Towards new agrivoltaic schemes. Renew. Energy 2011, 36, 2725-2732. [CrossRef]

50. Dinesh, H.; Pearce, J.M. The potential of agrivoltaic systems. Renew. Sustain. Energy Rev. 2016, 54, 299-308. [CrossRef]

51. United Nations. Sustainable Development Goals. 2020. Available online: https://www.un.org/sustainabledevelopment/ sustainable-development-goals / (accessed on 28 November 2020). 